\begin{abstract}
Iranica
Abstracta Iranica Revue bibliographique pour le domaine irano-aryen

Volume 32-33 | 2013

Comptes rendus des publications de 2009-2010
\end{abstract}

\title{
Reinhold Bichler. Der Hof der Achaimeniden in den Augen Herodots
}

\section{Astrid Nunn}

\section{(2) OpenEdition}

1 Journals

\section{Édition électronique}

URL : http://journals.openedition.org/abstractairanica/40191

DOI : 10.4000/abstractairanica.40191

ISSN : 1961-960X

Éditeur :

CNRS (UMR 7528 Mondes iraniens et indiens), Éditions de l'IFRI

\section{Édition imprimée}

Date de publication : 1 décembre 2013

ISSN : 0240-8910

\section{Référence électronique}

Astrid Nunn, "Reinhold Bichler. Der Hof der Achaimeniden in den Augen Herodots », Abstracta Iranica [En ligne], Volume 32-33 | 2013, document 36, mis en ligne le 01 juillet 2016, consulté le 28 septembre 2020. URL : http://journals.openedition.org/abstractairanica/40191 ; DOI : https://doi.org/10.4000/ abstractairanica.40191

Ce document a été généré automatiquement le 28 septembre 2020.

Tous droits réservés 


\title{
Reinhold Bichler. Der Hof der Achaimeniden in den Augen Herodots
}

\author{
Astrid Nunn
}

\section{RÉFÉRENCE}

Reinhold Bichler. « Der Hof der Achaimeniden in den Augen Herodots », in : Bruno Jacobs, Robert Rollinger, eds., « Der Achämenidenhof / The Achaemenid Court ». Akten des 2. Internationalen Quolloquiums zum Thema « Vorderasien im Spannungsfeld klassischer und altorientalischer Überlieferungen », Landgut Castelen bei Basel, 23.-25. Mai 2007. Wiesbaden, 2010, p. 155-187. (Classica et Orientalia(CLeO), 2)

1 R. Bichler, membre de "l'École d'Innsbruck", s'intéresse non seulement à ce que l'on peut tirer d'informations sur la cour achéménide chez Hérodote, mais aussi au " phénomène Cour » et au modèle de cour qui sous-tend les récits de cet auteur grec. Chronologiquement Hérodote débute avec les royautés des Lydiens et des Mèdes. Déjà pour cette époque ses descriptions sont sous-tendues par l'idée qu'avait Hérodote d'une société anatolienne immensément riche mais vivant dans des palais très sobres. Cette contradiction continue à exister à l'époque des Grands Rois, tant au niveau de l'Empire qu'à celui des royaumes de province. Cette richesse sera pour Hérodote la source de la puissance achéménide, mais aussi celle de sa disparition (voir c.r. $n^{\circ} 127$ ). 


\section{AUTEURS}

\section{ASTRID NUNN}

Université de Munich 